\title{
Research on Rights Protection of Political Participation of Returned Overseas Chinese
}

\author{
Feng Tong ${ }^{1}$, Chuangxin Sheng ${ }^{1}$, Yifan $\mathrm{Cao}^{2, *}$, Quan Xia $^{3, *}$ \\ ${ }^{1}$ Jinan University, Human Resources Development and Management Division, Guangdong, Guangzhou, \\ 510632 \\ ${ }^{2}$ Jinan University, School of journalism \&communication, Guangdong, Guangzhou, 510632 \\ ${ }^{3}$ Jinan University, Literature Institute, Guangdong, Guangzhou, 510632
}

Keywords: Rights protection, Political participation, Returned overseas Chinese

\begin{abstract}
With the profound changes of the world, the situation of overseas Chinese is also changed. More and more overseas Chinese have returned to invest or settle down. It is increasingly becoming one of the rights and interests of the overseas Chinese to participate in the political participation of the returned overseas Chinese. This paper analyzes the specific forms of the protection of the rights and interests of returned overseas Chinese in participating in government and state affairs and gives the paths to improve the system of overseas Chinese participation in the administration of state power to provide some references for the relative researchers.
\end{abstract}

\section{Introduction}

An overseas Chinese is a Chinese citizen with Chinese nationality, and a foreigner in the country of residence [1]. A foreigner in international law refers to a person who has other nationality or stateless nationality in a country that does not have the nationality of the country of residence. From the perspective of international law, the overseas Chinese have congealed two different legal relations. On the one hand, based on the legal relationship of nationality, overseas Chinese are protected by their country of nationality, and on the other hand, the country of residence is based on their territorial jurisdiction. Foreigners shall abide by the laws of the country of residence not limited to the laws of their entry and should abide by the new or amended laws during the period of residence. Under the jurisdiction of the country of residence, the overseas Chinese must not violate the laws and decrees of the country of residence, but because they are not the citizens of the country of residence, overseas Chinese do not enjoy the basic political rights of the country of residence. This is determined by the territorial jurisdiction of the national jurisdiction that embodies the sovereignty of the state. After the reform and opening, the reform of all aspects of socialism in China has been deepened. Overseas compatriots are more concerned about the progress and strength of the motherland, besides their support for their economic development, and the enthusiasm for participating in national affairs is also increasing. However, because of the limited platform, especially for overseas Chinese, these principles are not strong enough to operate and ignore the right to participate in the political affairs of the overseas Chinese. If overseas Chinese do not go back to their original places to work or start businesses, it is not realistic to ask them to return to their places of origin or to register or vote before they go abroad. These measures to ensure their political rights and interests should be reflected when the time is ripe for revising the legislation in the future [2].

\section{Concrete Forms of Political Participation of Returned Overseas Chinese}

\subsection{Participate in Electoral Activities}

The right to vote and the right to be elected is the most basic content of a citizen's political 
participation in political power, and the spirit of democracy is entrusted to it. The National People's Congress by the province, autonomous region, municipality directly under the central government, the army and the overseas Chinese representatives elected group. This is enough to see that in the early days; the state attaches great importance to overseas vote. "Election law" has been amended several times, but this should be a separate overseas representative method is still not issued after the second amendment. "Election law" was formally clear the Chinese right to vote and stand for election. It provides "living overseas citizens in People's Republic of China during the election of deputies to people's congresses below the county level in domestic or abroad may participate in the origin place of residence before the election". Since then opened the prelude of the electoral system. Compared with the overseas Chinese overseas Chinese of the security interests, security degree of Guangdong overseas Chinese has power and grassroots people's Congress election mass organizations of self-government election rights is relatively low. Although Guangdong and more gradually realize the overseas Chinese political participation rights protection is an urgent need, but the overseas vote and enjoy the right to be elected and the exercise program, such as voter registration and electoral districts, the nomination, election ballot payment and other specific procedures, cannot reflect the particularity of the overseas Chinese. In the election, most of the Chinese who have the right to vote often take part in the election passively, and even take the command of some local powerful forces. From the current situation of the right to vote and the right to be elected, our current laws do not reflect the special situation of overseas Chinese and carry out targeted system design. Although some of the famous overseas Chinese villages have the rules to guarantee the participation of overseas Chinese in the right to vote and the right to be elected, these Provisions lack specific implementation paths, and the publicity is not in place. The significance of its promulgation is far greater than the actual effect [3].

\subsection{Hold Public Office}

Citizenship is a form of citizen participation in public affairs, because citizens can directly participate in the formulation and implementation of national policies and policies after holding public office. It is also the most direct and effective way for the overseas Chinese to take part in the formulation and implementation of the national policy. However, the existing laws and regulations do not make clear whether the overseas Chinese can hold a state public office or that the possibility of overseas Chinese holding state office is difficult to guarantee. Civil servants should have the nationality overseas Chinese as Chinese citizens have the right to apply for the examination of the civil service. However, at present, the national legislation of the overseas Chinese is involved in the examination of the rights and interests of the civil servants. The regulations make it clear that China's various sectors of production, construction, science, education, culture, commerce, finance and foreign trade can introduce overseas Chinese. The central level laws, regulations and even national policies have not yet made clear that overseas Chinese have the right to register for civil servants, that is, the protection system of overseas Chinese applicants at the central level is still absent. In accordance with the conditions of public selection of leading cadres, the public selection shall be taken in accordance with the relevant provisions. " This is the first municipal rule of the local government to make sure that overseas Chinese can apply for civil service examination. It further widens the scope and threshold of overseas applicants for civil service examination. However, the current local regulations that allow overseas Chinese to take the examination of the civil service are still too principled, lack of maneuverability, and even too narrow [4].

\subsection{Participate in the Chinese People's Political Consultative Conference}

The Chinese people's participation in the Chinese people's Political Consultative Conference (CPPCC) can be traced back to the first CPPCC National Conference. At that time, as an important force of Chinese democratic liberation movement, many overseas Chinese in addition to serving as a member of the CPPCC National Committee, also served as an important position of the country, such as the two-day trip overseas Chinese people's political consultative conference vice chairman of the first session of the national committee. Compared with other state organs, the CPPCC has no real 
"real power" and can only conduct political consultations, democratic supervision and participation in political and political activities. The Municipal People's political consultative conference invited overseas Chinese representatives from Thailand, Singapore, Malaysia and France to attend the plenary meetings of the CPPCC. The Shantou Municipal Council employed overseas Chinese representatives as a special member of the CPPCC and participated in the CPPCC activities to better play the role of the overseas Chinese think tank. However, whether as distinguished members, or to attend the CPPCC meeting, the overseas Chinese participation degree is not high, the number is not enough, really can play the role of the overseas members still need to be improved. Overseas Chinese is an important participant in The Belt and Road construction actively, can play a positive role in the "five links". In the policy of communication, people communicate, overseas Chinese played a unique advantage in two languages and two cultures, two for the domestic market, "going out" enterprises and local governments, banks, intermediary service institutions, employing institutions to achieve effective docking, and will play an important role.

\section{Improvement Paths of Perfecting Rights Protection System of Political Participation of Returned Overseas Chinese}

\subsection{Perfect Rights Protection System of Participating in Electoral Activities}

The legal protection of the right to vote and the right to be elected should be based on the actual situation of China. It is not mandatory for overseas Chinese to participate in the election as well as the citizens of the country. Overseas Chinese are based on the geographical location, can be divided into domestic and overseas election but no matter what, if the Chinese holding Chinese passports or to prove their China as citizens, such as providing civil witness testimony, genealogy, immigration records show, should have the right to participate in the election. Based on the experience of the overseas countries' participation in the administration of state affairs and the actual situation of our country, the state can set up three systems, such as the registration system of overseas Chinese voters, the voting system of overseas Chinese, and the voting system of overseas Chinese. Overseas voter registration system, which should be in accordance with the overseas Chinese hometown, the original place of residence registration, when Chinese foreign-born parents of origin and the original place of residence does not belong to the same place, freedom of choice by the overseas parent of origin or the original place of residence registration. The improvement of the overseas Chinese electorate system requires the establishment of an overseas Chinese population information base under the leadership of the Department of overseas Chinese affairs of the State Council. The election authorities to determine the qualification of voters by the overseas Chinese population information database. The overseas Chinese entrust the electoral system, that is, before the end of the election, the overseas Chinese can entrust the domestic citizens to vote by means of written and e-mail. The same domestic voter can accept a maximum of three overseas Chinese. The voting system for overseas Chinese, that is, the establishment of overseas voting sites by relevant departments, or overseas Chinese, sends votes to the electoral authorities through written and e-mail. If the overseas Chinese are in the country and are willing to participate in the electoral activities, they should participate in the electoral activities in accordance with the current electoral law. If the overseas Chinese live in the residence of the household registration during the election period, the right to vote and the right to vote shall be enjoyed, regardless of the length of residence.

\subsection{Perfect Rights Protection System of Holding Public Office}

Based on the particularity of the overseas Chinese, the way for the overseas Chinese to apply for the civil servants should be applied to the people, and it is impossible to apply the domestic standards to the overseas Chinese. Therefore, the examination papers of the civil service examination can refer to the national judicial examination. There are minority languages, traditional Chinese and even foreign languages. Limited by the educational system of our country and the common language of the international community, the foreign language is tentatively designated as the second other foreign 
language in English or overseas Chinese to reduce the difficulty and cost of civil service examination reform. In addition, if there are no conditions for the implementation of multilingual civil service examination papers in China after the demonstration by relevant departments in China, it is possible to pilot the work in some places where overseas Chinese have already applied for civil service or a famous overseas Chinese town. When the local management experience, then gradually extended to the country. Equality of opportunity is the primary requirement for the protection of public power. The position of public office is limited, it is impossible for every citizen to hold a public office, but first, we must ensure that citizens have equal opportunities to hold public office and participate in official duties. In the comprehensive promotion of "The Belt and Road" initiative situation, to broaden the scope of China's diplomacy, enhance China's international influence, attract more foreign capital to our country construction, it is necessary to make full use of overseas Chinese groups this precious national resources, in overseas Chinese Affairs Department, the Department of foreign affairs, the Department of commerce can be individually set some special recruitment Posts overseas compatriots. If the number of overseas Chinese compatriots for the year is too small, also can be relaxed to returned overseas Chinese and their relatives, students and other groups, gradually increase the foreign well-known overseas Chinese groups in the proportion of official team, truly embodies the Chinese citizens apply for civil rights for equality of opportunity.

\subsection{Perfect Rights Protection System of Participating in Chinese People's Political Consultative Conference}

The CPPCC is the patriotic united front of the Chinese people. It is different from the legislature of the people's Congress. The main function of the CPPCC is to offer advice and advice, allowing overseas Chinese to make suggestions and suggestions, which will not affect the national interests. The advantage of allowing overseas Chinese to participate in political consultations and political consultations is that overseas Chinese live abroad all the year round, and even a large proportion of overseas Chinese live in developed areas. They are all advanced theories and practical experiences in democratic politics and consultative work in the settlement countries. Overseas Chinese participation in politics and politics can draw lessons from our minds, integrate intelligence resources, give full play to the functions of the CPPCC's think tank, and promote the CPPCC's work through demonstration, discussion and suggestion. The constitution is expressed as the most widespread patriotic united front. It certainly includes many overseas Chinese. Chinese people's Political Consultative Conference National Committee of the Communist Party China, all democratic parties and personages without party affiliation and people's organizations, ethnic minorities and representatives of the people from all walks of life, on behalf of the Hongkong and Macao compatriots, Taiwan compatriots and returned overseas Chinese and specially invited, a plurality of sectors. As a result, the "special invitation" and "a number of constituencies" have left space for the overseas Chinese to serve as members of the CPPCC. It is necessary for the state to standardize the CPPCC. There are two kinds of political participation in the Chinese people's Political Consultative Conference.

\section{Conclusions}

As a Chinese citizen, the overseas Chinese should be equal to the citizens of the country and enjoy the political power to participate in the government as stipulated in the constitution. It is a typical legislative inaction that the current legislation neglects the political power of the overseas Chinese to participate in political power, which violates the requirements of the universality and equality of the citizens' political participation.

\section{Acknowledgements}

This research is the results of General Project of All-China Federation and Returned Overseas Chinese Subject from 2017 to 2019 named "Research on Rights Protection of Political Participation 
of Returned Overseas Chinese" (Grant No. 17BZQK214) and results of Teaching Research and Reform Project of Higher Education of Guangdong Province of Guangdong Provincial Education Department named "Mechanism Reform Research on Career Planning and Cultivation of Young Teachers of High Level in Guangdong Colleges and Universities" (Grant No. 006940116 /201600981).

\section{References}

[1] Jin Zhengkun, Zhu Lingfeng. The Modes of Political Participation of Overseas Chinese: Examples from the US, Malaysia and the UK [J]. Southeast Asian Studies, 2016(6): 92-100.

[2] Hongwei Yuan, Analysis of Characteristics of the Rural Political Participation in Yan'an Period [J]. Asian Agricultural Research 2015, 7( 12): 59-62.

[3] Zhang Saiqun. On the Overseas Chinese's Political Participation in PRC [J]. Journal of Jiangsu University (Social Science Edition), 2011, 13(6): 32-36+41.

[4] Yan Kang, Jianbin Fang. Empirical Study on Online Political Participation of Young Migrant Workers [J]. Asian Agricultural Research 2015, 7(7) : 89-91. 